\title{
PENGARUH PENGGUNAAN GADGET DENGAN PRESTASI BELAJAR PADA SISWA/SISWI SMAN 2 TEMBILAHAN
}

\author{
Haryati Astuti \\ Akademi Kebidanan Husada Gemilang Tembilahan \\ Email: haryatibachtiar1@gmail.com (korespondensi)
}

\begin{abstract}
Gadget are phones that have capabilities such as computers, usually have large screens and the operating system is capable of carrying out common applications. Throughout the world there are 76.9 billion gadget usage and will continue to increase. The impact of the use of gadget can have an adverse impact on adolescents, it is known that the mass media or in this case the internet has a big impact on behavior change, such as playing games, watching porn videos and having unlimited relationships with girlfriends. The purpose of this study was to find out the description of the use of gadgets with the learning achievement of students of SMAN 2 Tembilahan in 2018. This research is descriptive with a cross sectional approach. The population in this study were all students of class XI and XII, with the sampling method carried out in proportionate stratified random sampling, as many as 117 samples, carried out on 28 Agustus 2018. The results of this study that use the majority of gadgets have a majority of unfavorable learning achievement as many as 41 people (56.2\%) and the negative using the majority gadget also has a bad learning achievement of 52 people (71.2\%). It is hoped that this research will be used as a reference for schools on the impact of gadget use, so that this research can later be used by students to improve learning achievement, and can provide additional information for further researchers by replacing or adding existing variables related to the description of gadget usage, learning in adolescents.
\end{abstract}

Keywords: Gadget usage, Learning achievement

\begin{abstract}
Abstrak
Gadget adalah telepon yang memiliki kemampuan seperti komputer, biasanya memiliki layar yang besar dan sistem operasinya mampu menjalankan tujuan aplikasi-aplikasi yang umum. Diseluruh dunia terdapat 76,9 miliar penggunaan gadgetdan akan terus meningkat. Dampak penggunaan gadgetdapat memberikan dampak tidak baik pada remaja diketahui bahwa media massa atau dalam hal ini internet memberikan dampak yang besar terhadap perubahan perilaku, seperti bermain games, menonton vidio porno dan berhubungan tanpa batas dengan pacar. Tujuan penelitian ini untuk mengetahui gambaran penggunaan gadget dengan prestasi belajar pada siswa/siswi SMAN 2 Tembilahan Tahun 2018. Penelitian ini bersifat Diskriptif dengan pendekatan cross sectional. Populasi dalam penelitian ini suluruh siswa/siswi kelas XI dan XII, dengan metode pengambilan sampel dilakukan dengan secara proportionate stratified random sampling yaitu sebanyak 117 sampel, dilaksanakan pada tanggal 28 Agustus 2018. Hasil penelitian ini yang positif menggunakan gadget mayoritas memiliki prestasi belajar tidak baik sebanyak 41 orang (56,2\%) dan yang negatif menggunakan gadget mayoritas juga memiliki prestasi belajar tidak baik sebanyak 52 orang (71,2\%). Diharapkan bahwa penelitian ini akan digunakan sebagai referensi bagi sekolah terhadap dampak penggunaan gadget, sehingga penelitian ini nantinya dapat digunakan oleh siswa untuk meningkatkan prestasi belajar, dan dapat memberikan informasi tambahan bagi peneliti selanjutnya dengan mengganti atau menambahkan variabel yang ada terkait dengan deskripsi penggunaan gadget, belajar pada remaja.
\end{abstract}

Kata kunci: Penggunaan gadget, Prestasi belajar

\section{PENDAHUlUAN}

Gadget adalah telepon yang memiliki kemampuan seperti komputer, biasanya memiliki layar yang besar dan sistem operasinya mampu menjalankan tujuan aplikasi-aplikasi yang umum. gadget memiliki fitur berupa akses internet, dan sistem operasi yang mampu mengunduh berbagai macam aplikasi seperti games, media sosial, 
email, dan aplikasi lain. Dampak pengguna gadget memiliki beberapa dampak pada kehidupan manusia yaitu pada bisnis, pendidikan, kesehatan, dampak psikologis dan dampak sosial [8].

Internet memang memudahkan kita dalam mengakses beragam situs sesuai dengan kebutuhan pengguna jasa alat elektronik modern tersebut yang berkaitan dengan bisnis, hobi, pendidikan, pertemanan, bahkan transaksi bisa melalui internet. Pentingnya keberadaan internet mendorong sebagian orang untuk terhubung dengan jaringan internet untuk memudahkan mereka dalam keseharian [7].

Berdasarkan hasil penelitian Putri (2016) Hubungan Tingkat Penggunaan Smartphone pada Remaja dengan Interaksi dalam Keluarga yaitu pengguna telepon seluler di dunia mengalami perkembangan yang pesat dalam dua dekade terakhir ini, baik di negara maju ataupun negara sedang berkembang. Laporan itu sejalan dengan penelitian terbaru IDC, yang memprediksi jumlah download aplikasi mobile sebesar 10,9 miliar pada tahun 2010 menjadi 76,9 miliar pada 2014 $[7,10]$.

Pengguna gadget di Indonesia sebanyak 1,3 Juta pada tahun 2009 dan akan bertambah mencapai 18,7 juta pada tahun 2015. Menurut Market penggunaan gadget pada tahun 2016 mencapai 65,52 juta, tahun 2017 74,9 juta dan Tahun 2018 dan 2019 akan terus berkembang. Asosiasi Penyelenggara Jasa Internet Indonesia (APIJI) juga melakukan survey yang menunjukkan bahwa Tahun 2012 jumlah pengguna internet yang mengakses lewat gadget di Indonesia mencapai 65,7 \% dibanding komputer dan leptop [2].

Jumlah penduduk berumur 10 tahun keatas yang bisa membaca di Kota Pekanbaru Tahun 2015 berjumlah 835.375 orang $(99,90 \%)$. Porsi terbesar tingkat pendidikan tertinggi yang ditamatkan penduduk Pekanbaru adalah sekolah Menengah Atas (SMA dan sejenis) dengan pesentase $43.2 \%$ dari jumlah penduduk kota Pekanbaru berumur 10 tahun ke atas dan hampir semua menggunakan gadget Tahun 2015 [2].

Berdasarkan data penduduk di Kabupaten Indragiri Hilir tercatat tahun 2017 lalu terdapat \pm 520.030 orang berumur 12 tahun keatas dari keseluruhan terhitung dari jumlah penduduk laki-laki sebanyak 259,965 dan perempuan sebayank 260.015 orang. Diperkirakan dari jumlah penduduk Inhil hampir semua menggunakan gadget untuk kebutuhan pribadi masing-masing [2].

Berdasarkan hasil penelitian Rohmah (2017) Pengaruh Penggunaan gadget dan
Lingkungan Belajar terhadap minat belajar siswa kelas XI Kompetensi Keahlian Administrasi Perkantoran SMK Muhammadiyah 2 Yogyakarta dimana populasi penelitian adalah Student Grade XI Office Administration Competence SMK Muhammadiyah 2 Yogyakarta berjumlah 47 siswa dengan menggunakan purposive teknik sampling sehingga sampel berjumlah 41 siswa. Teknik pengumpulan data menggunakan kuesioner dan dokumentasi. Teknik analisis data dilakukan dengan analisis deskriptif, analisis regresi sederhana dan berganda setelah tes prakondisi telah melakukannya. Hasil penelitian menunjukkan bahwa jumlah 23,3\% ada efek positif dengan penggunaan gadget dan kategori tinggi negatif dalam jumlah 58,54\% dan pembelajaran lingkungan dalam kategori tidak baik dalam jumlah $54 \%$ pengaruh penggunaan gadget dan lingkungan belajar yang sesuai untuk belajar minat dalam jumlah $42,1 \%$, ada efek positif dengan minat belajar pada kategori negatif sebesar $53,66 \%$ [7].

Berdasarkan hasil penelitian Oktario (2017) Hubungan antara Intesitas Penggunaan gadget dan Motivasi Berprestasi pada Mahasiswa yaitu pada remaja gadget (handphone), lingkungan akademis seseorang yang menggunakan gadget memang dapat di mudahkan dalam beraktifitas, tetapi juga dapat memberikan dampak tidak baik (72\%) pada remaja diketahui bahwa media massa atau dalam hal ini internet memberikan dampak yang besar terhadap perubahan perilaku dan presepsi penggunaannya satu faktor terbesar remaja melakukan perilaku seksual adalah melihat konten porno di internet terutama vidio. Mengapa demikian, karena dengan melihat hal-hal yang berbau seksual akan berpengaruh secara kognitif serta dapat merefleksikan aktivitas tersebut dalam bentuk imajinasi dan tindakan $[7,9]$.

Hasil survei pendahuluan di SMAN 2 Tembilahan pada tanggal 4 Mei 2018 jumlah siswa/siswi di SMAN 2 Tembilahan seluruh siswa/siswi laki-laki dan perempuan sebanyak 166 orang, untuk seluruh siswa kelas XI sebanyak 68 orang dan kelas XII sebanyak 98 orang, Berdasarkan data dari BK dari semua siswa/siswi tersebut hampir semuanya mempunyai gadget pribadi masing-masing. Itu di buktikan saat dilaksanakannya razia setiap 6 bulan sekali, terdapat 10 orang siswa/siswi yang kedapatan membawa gadget di sekolah, terdapat gadget berisi vidio pornografi yang tidak layak di tonton dan hampir semua gadget berisi game online. Berdasarkan 
uraian di atas sesuai pada aturan kesiswaan siswa/siswi tidak boleh membawa gadget dan dampak buruk yang di hasilkan dari menggunakan gadget di sekolah maka peneliti tertarik untuk melakukan penelitian lebih lanjut mengenai "Gambaran Penggunaan Gadget dengan Prestasi Belajar pada Siswa/Siswi SMAN 2 Tembilahan Tahun 2018".

\section{TINJAUAN PUSTAKA}

\subsection{Gadget}

a. Definisi Gadget

Berdasarkan hasil penelitian Oktario (2017) Hubungan antara Intensitas Penggunaan Gadget dan Motivasi Berprestasi Pada Mahasiswa yaitu dimana gadget adalah telepon yang memiliki kemampuan seperti komputer, biasanya memiliki layar yang besar dan sistem operasinya mampu menjalankan tujuan aplikasiaplikasi yang umum. Gadget memiliki fitur berupa akses internet, dan sistem operasi yang mampu mengunduh berbagai macam aplikasi seperti games, media sosial, email, dan aplikasi lain. Menurut Backer dalam penelitian Oktario (2017) menyatakan bahwa gadget adalah telepon yang menyatukan kemampuan-kemampuan terdepan ini merupakan bentuk kemampuan dari Wireless Mobile Device (WMD) yang dapat berfungsi seperti sebuah komputer dengan menawarkan fitur-fitur seperti Personal Digital Assistant (PDA), akses internet, email, dan Global Positioning System (GPS) [7].

b. Dampak pengguna Gadget

Berdasarkan hasil penelitian Oktario (2017) Hubungan antara Intensitas Penggunaan gadget dan Motivasi Berprestasi Pada Mahasiswa dimana Menurut Sarwar 2013, penggunaan gadget memiliki beberapa dampak pada kehidupan manusia, yakni:

1) Bisnis

Penggunaan gadget berpengaruh pada kenaikan pertumbuhan penjualan dan pertumbuhan perkembangan aplikasi dalam gadget tersebut. Hal tersebut juga dapat menyebabkan semakin banyak pengguna yang menggunakan gadget. Para pengguna semakin banyak menggunakan gadget yang dirasa lebih ringkas dalam keseharianya.

2) Pendidikan
Pendidikan berperan dalam merubah hidup manusia menjadi lebih baik. Perkembangan dalam dunia pendidikan juga semakin berkembang seiring waktu. Semakin berkembangnya konsep pendidikan yang ada, dituntut pula kemudahan dalam mengakses pendidikan tersebut. Salah satunya adalah penggunaan gadget dalam dunia pendidikan. Walaupun tetap ada dampak lain yang muncul seperti halnya pada penggunaan mengirim untuk berkirim pesan, media sosial, mengecek email, bermain games, atau menonton video dari internet. Hal tersebut dapat menjadi salah satu gangguan bagi pelajar tersebut bahkan lingkungan sekitarnya. Seperti mengecek email yang masuk, atau bahkan melakukan tindakan yang kurang baik seperti mencotek dengan gadget. Hal lain yang dapat disalah gunakan yakni menjadikan gadget sebagai alat bantu dalam tindakan pembulian.

3) Kesehatan

Saat ini banyak sekali pengguna yang memanfaatkan gadget dan tabletnya untuk mengakses informasi mengenai kesehatan. Dalam perkembanganya ke depan diperkirakan kemunculan aplikasiaplikasi yang dapat memantau kondisi kesehatan secara penuh yang dapat di lihat langsung oleh petugas medis. Penggunaan gadget yang mudah dengan sekali klik dan sentuh sangat memudahkan dalam prakteknya. Hal tersebut juga dapat memunculkan beberapa dampak lainya, yakni:

a) Menjauhkan anak dari interaksi sosial dengan orang lain secara bertemu dan berdinamika secara langsung.

b) Penggunaan yang tidak terkontrol dapat menurunkan kinerja mata pada anak.

c) Penggunaan pada gadget membuat anak terlalu cepat dalam mengambil suatu keputusan berdasarkan informasi yang sedikit dari pada berfokus dan mencari informasi sedetail mungkin. Hal ini akan berdampak pada perkembangan otak. Game 
dan online merupakan hal yang menyenangkan bagi anak-anak. Hal tersebut memerlukan waktu yang tidaklah sedikit dalam mengaksesnya. Anak akan cenderung ketagihan dalam mengaksesnya dan akan menjadi dampak yang tidak baik dalam perkembanganya.

4) Dampak Psikologis

Berdasarkan survei menunjukkan pengaruh gadget dapat mengurangi stres pada pengguna dalam aktifitas keseharianya. gadget membantu pengguna dalam memudahkan interaksi dengan teman dan keluarga dalam keseharian serta membantu untuk up to date dengan informasiinformasi baru yang tengah beredar.

5) Dampak Sosial

Berdasarkan riset sekitar $15 \%$ jumlah populasi dunia memiliki disabilitas dan jumlah orang yang semakin tua pun bertambah. gadget dapat membantu mereka untuk bisa hidup lebih mandiri. Fitur atau aplikasi yang terdapat pada gadget dapat membantu mereka seperti GPS, web sosial, dan text to speech. Berdasarkan hal tersebut gadget dinilai dapat menjadi jembatan bagi orang yang memiliki disabilitas dan orang tua [7].

\subsection{Prestasi Belajar}

a. Definisi Prestasi Belajar

Berdasarkan hasil penelitian Febrian (2014) Hubungan Antara Konsep diri dengan Prestasi Belajar Siswa Kelas XII IPA 2 Tahun Ajaran 2013/2014 di SMA Dharma Putra Tangerang dimana prestasi belajar adalah hasil dari suatu proses yang dinyatakan dalam bentuk angka sebagai proses evaluasi yang diberikan pada akhir semester dalam bentuk rapor. Pendapat lain dari Wuryani dalam penelitian Febrian (2014) menyatakan bahwa prestasi belajar adalah hasil yang dicapai oleh siswa selama berlangsungnya proses belajar dan diberikan oleh pengajar dalam jangka waktu yang sudah ditentukan sebagai hasil penilaian belajar $[7,4]$.

b. Dampak Gadget bagi prestasi belajar Berdasarkan hasil penelitian Oktario
(2017) Hubungan antara Intensitas Penggunaan Gadget dan Motivasi Berprestasi Pada Mahasiswa dimana gadget memiliki dampak tertentu pada penggunanya. Sarwar dalam penelitian Oktario (2017), menyatakan bahwa gadget memiliki dampak yang positif dan negatif. Dampak positif yang ada pada gadget yakni memudahkan komunikasi, memudahkan dalam melakukan aktifitasnya menjadi lebih efektif dan efisien, serta tidak terbatas oleh waktu. Gadget juga memiliki dampak yang berpengaruh pada motivasi berprestasi. Bila penggunaan gadget kurang tepat dapat mempengaruhi motivasi berprestasi seseorang menjadi menurun dan dapat mempengaruhi pada pencapaian prestasi akademisnya [7].

Gadget memiliki banyak fitur menarik salah satunya hiburan dan fitur sosial lainya. Karena kemudahan penggunaan dalam mengakses tanpa batasan waktu, bahkan ketika proses pembelajaran sedang berlangsung dapat menurunkan motivasi berprestasi seseorang. Dalam mencapai prestasinya mahasiswa membutuhkan motivasi yang mampu menggerakan. Wigunantiningsih dalam penelitian Oktario (2017) menyatakan bahwa tingkat motivasi belajar yang semakin meningkat pada mahasiswa maka akan berpengaruh pada prestasi belajarnya. Hal tersebut dapat dinyatakan juga bila seorang yang memiliki tingkat motivasi berprestasi yang tinggi maka prestasi akademisnya dapat tercapai. Seseorang yang seharusnya dapat memaksimalkan waktunya untuk belajar dan berusaha dalam proses pembelajaran, namun lebih memilih untuk menggunakan gadget untuk hal yang tidak terkait dengan pembelajaran. Hal tersebut memang tidak dilarang karena gadget memang dapat memfasilitasi banyak hal. Namun jika penggunaan yang kurang tepat tersebut dalam intensitas yang tinggi hal tersebut dapat menjadi pengaruh pada motivasi berprestasi. Bila penggunaan yang kurang tepat tersebut intensitasnya tinggi dapat menurunkan motivasi berprestasi pada seseorang. Bila motivasi berprestasi tersebut turun, akan menjadi kurang adanya upaya dalam mencapai prestasi akademis, sehingga prestasi akademis 
pun turun bahkan bisa tidak tercapai $[2,7]$.

2.3. Remaja

a. Definisi Remaja

Secara etimiologi, remaja berarti "tumbuh menjadi dewasa". Definisi remaja (adolescence) menurut organisasi kesehatan dunia (WHO) adalah priode usia antara 10 sampai 19 tahun. Definisi sendiri dapat ditinjau dari tiga sudut pandang, yaitu:

1) Secara kronogis, remaja adalah individu yang berusia antara 11-12 tahun sampai 20-21 tahun.

2) Secara fisik, remaja di tandai oleh ciri perubahan penampilan fisik dan fungsi fisiologis, terutama yang terkait dengan kelenjer seksual.

3) Secara psikologis, remaja merupakan masa dimana individu mengalami perubahan-perubahan dalam aspek kognitif, emosi, social, dan moral di antara masa anakanak menuju dewasa [8].

b. Masa Remaja

Rentang waktu usia remaja menurut Monks, Knoers, dan Haditono membedakan masa remaja menjadi empat bagian, yaitu masa pra-remaja 10-12 tahun, masa remaja awal 12-15 tahun, masa remaja pertengahan 1518 tahun, dan masa remaja akhir 1821 tahun

Definisi yang dipaparkan oleh Sri Rumini \& Siti Sundari, Zakiah Darajat, dan Santrock tersebut mengambarkan bahwa masa remaja adalah masa peralihan dari masa anak-anak dengan masa dewasa dengan rentang usia antara 12-22 tahun, dimana pada masa tersebut terjadi proses pematangan baik itu pematangan fisik, maupun pematangan psikologis [8].

\section{METOdOLOGI PENELITIAN}

Penelitian ini bersifat diskriptif Dalam penelitian ini populasinya adalah kelas XI dan XII di SMAN 2 Tembilahan. Teknik pengambilan sample adalah menggunakan probabiliy sampling dengan teknik menggunakan proportionate stratified random sampling yang berjumlah 177 orang. Penelitian dilakukan di SMAN2 Tembilahan pada tanggal 28 Agustus 2018.

\section{HASIL DAN PEMBAHASAN}

\subsection{Hasil}

Setelah dilakukan penelitian tentang "Gambaran Penggunaan Gadget Dengan Prestasi Belajar Pada Siswa/siswi SMAN 2 Tembilahan Tahun 2018" tehadap 117 orang siswa/siswi, dipereloh hasil sebagai berikut :

a. Distribusi frekuensi penggunaan gadget pada siswa/siswi SMAN 2 Tembilahan.

Tabel 4.1 Distribusi Frekuensi Penggunaan Gadget Pada Siswa/siswi Di SMA 2 Tembilahan Tahun 2018

\begin{tabular}{ccc}
\hline $\begin{array}{c}\text { Penggunaan } \\
\text { Gadget }\end{array}$ & Frekuensi & Persentase \\
\hline Positif & 44 & $37,6 \%$ \\
Negatif & 73 & $62,4 \%$ \\
\hline Jumlah & $\mathbf{1 1 7}$ & $\mathbf{1 0 0} \%$ \\
\hline
\end{tabular}

Berdasarkan tabel 4.1 didapatkan hasil mayoritas responden menggunakan gadget negatif dalam penggunaan gadget (browsing, game, chatting, sosial media BBM, Instagram, Path, WatsApp, Line, Snapchat) sebanyak 73 orang $(62,4 \%)$.

b. Distribusi frekuensi prestasi belajar pada siswa/siswi SMAN 2 Tembilahan.

Tabel 4.2 Distribusi Frekuensi Prestasi belajar Pada Siswa/siswi Di SMA 2 Tembilahan Tahun 2018

\begin{tabular}{ccc}
\hline Prestasi Belajar & Frekuensi & Persentase \\
\hline Baik & 24 & $20,5 \%$ \\
Tidak baik & 93 & $79,5 \%$ \\
\hline Jumlah & $\mathbf{1 1 7}$ & $\mathbf{1 0 0 \%}$ \\
\hline
\end{tabular}

Berdasarkan tabel 4.2 didapatkan hasil mayoritas responden memiliki prestasi belajar tidak baik sebanyak 93 orang $(79,5$ $\%)$.

c. Gambaran penggunaan gadget dengan prestasi belajar pada siswa/siswi SMAN 2 Tembilahan.

Tabel 4.3 Distribusi Frekuensi Penggunaan Gadget dengan Prestasi Belajar Pada Siswa/siswi Di SMA 2 Tembilahan Tahun 2018

\begin{tabular}{crrrrrr}
$\begin{array}{c}\text { Penggunaan } \\
\text { Gadget }\end{array}$ & \multicolumn{2}{c}{ Baik } & \multicolumn{2}{c}{ Tidak baik } & & \\
& F & \multicolumn{1}{c}{$\%$} & \multicolumn{1}{c}{ F } & \multicolumn{1}{c}{$\%$} & & \\
\hline Positif & 3 & 4,1 & 41 & 56,2 & 44 & 37,6 \\
Negatif & 21 & 28,8 & 52 & 71,2 & 73 & 62,4 \\
\hline Jumlah & 24 & 20,5 & 93 & 79,5 & 117 & 100 \\
\hline
\end{tabular}

Berdasarkan tabel 4.3 didapatkan hasil yang positif menggunakan gadget mayoritas memiliki prestasi belajar tidak baik sebanyak 41 orang $(56,2 \%)$ dan yang negatif 
menggunakan gadget mayoritas juga memiliki prestasi belajar tidak baik sebanyak 52 orang $(71,2 \%)$.

\subsection{Pembahasan}

Berdasarkan hasil penelitian bahwa mayoritas siswa/siswi negatif dalam menggunakan gadget (browsing, game, chatting, sosial media BBM, Instagram, Path, WatsApp, Line, Snapchat) sebanyak 73 orang $(62,4 \%)$ dan mayoritas responden memiliki prestasi belajar tidak baik sebanyak 93 orang $(79,5 \%)$. Serta gambaran penggunaan gadget dengan prestasi belajar mayoritas yang positif menggunakan gadget memiliki prestasi belajar tidak baik sebanyak 41 orang $(56,2 \%)$ dan yang negatif menggunakan gadget mayoritas juga memiliki prestasi belajar tidak baik sebanyak 52 orang (71,2\%).

Penelitian ini sejalan dengan penelitan Rohmah (2017) hasil penelitian menunjukkan bahwa jumlah $(23,3 \%)$ ada efek positif dengan penggunaan gadget dan kategori tinggi negatif dalam jumlah $(58,54 \%)$ dan pembelajaran lingkungan dalam kategori tidak baik dalam jumlah (54\%) pengaruh penggunaan gadget dan lingkungan belajar yang sesuai untuk belajar minat dalam jumlah $(42,1 \%)$, ada efek positif dengan minat belajar pada kategori negatif sebesar (53,66\%) (http://eprints.uny.ac.id Diakses pada tanggal 26 September 2018).

Penggunaan gadget berperan dalam merubah hidup manusia menjadi lebih baik. Perkembangan dalam dunia pendidikan juga semakin berkembang seiring waktu. Semakin berkembangnya konsep pendidikan yang ada, dituntut pula kemudahan dalam mengakses pendidikan tersebut. Salah satunya adalah penggunaan gadget dalam dunia pendidikan. Penggunaan gadget berguna untuk berkirim pesan, media sosial, mengecek email, bermain games, atau menonton video dari internet. Hal tersebut dapat menjadi salah satu gangguan bagi pelajar tersebut bahkan lingkungan sekitarnya [9].

Prestasi belajar dikatakan sempurna apabila memenuhi tiga aspek, antara lain aspek kognitif, afektif, dan psikomotor. Aspek kognitif berhubungan dengan pengenalan baru atau mengingat kembali (menghafal), memahami, mengaplikasikan, menganalisis, dan kemampuan mengevaluasi. Aspek afektif berhubungan dengan pembangkitan minat, sikap/emosi, penghormatan (kepatuhan) terhadap nilai atau norma. Aspek psikomotor berhubungan dengan pengajaran yang bersifat keterampilan atau yang menunjukkan kemampuan (skill) [4].

Penggunaan gadget kurang tepat dapat mempengaruhi motivasi berprestasi seseorang menjadi menurun dan dapat mempengaruhi pada pencapaian prestasi akademisnya. Apabila seorang yang memiliki tingkat motivasi berprestasi yang tinggi maka prestasi akademisnya dapat tercapai. Seseorang yang seharusnya dapat memaksimalkan waktunya untuk belajar dan berusaha dalam proses pembelajaran, namun lebih memilih untuk menggunakan gadget untuk hal yang tidak terkait dengan pembelajaran. Hal tersebut memang tidak dilarang karena gadget memang dapat memfasilitasi banyak hal. Namun jika penggunaan yang kurang tepat tersebut dalam intensitas yang tinggi hal tersebut dapat menjadi pengaruh pada motivasi berprestasi. Bila penggunaan yang kurang tepat tersebut intensitasnya tinggi dapat menurunkan motivasi berprestasi pada seseorang. Bila motivasi berprestasi tersebut turun, akan menjadi kurang adanya upaya dalam mencapai prestasi akademis, sehingga prestasi akademis pun turun bahkan bisa tidak tercapai

Dengan adanya gadget dapat meningkatkan prestasi belajar seseorang apabila digunakan untuk proses pembelajaran, namun akan menurunkan prestasi belajar jika digunakan hanya untuk bermain gadget (browsing, game, chatting, sosial media BBM, Instagram, Path, WatsApp, Line, Snapchat) dikarenakan selalu menyianyiakan waktu hanya untuk menggunkan gadget.

\section{KESIMPULAN DAN SARAN}

Dari hasil penelitian diperoleh Distribusi frekuensi penggunaan gadget pada siswa/siswi SMAN 2 Tembilahan mayoritas negatif sebanyak 73 orang $(62,4 \%)$. Distribusi frekuensi prestasi belajar pada siswa/siswi SMAN 2 Tembilahan mayoritas tidak baik sebanyak 93 orang (79,5\%). Gambaran penggunaan gadget dengan prestasi belajar pada siswa/siswi SMAN 2 Tembilahan yaitu yang positif menggunakan gadget mayoritas memiliki prestasi belajar tidak baik sebanyak 41 orang $(56,2 \%)$ dan yang negatif menggunakan gadget mayoritas juga memiliki prestasi belajar tidak baik sebanyak 52 orang $(71,2 \%)$.

Saran bagi tempat penelitian Siswa/siswi sebaiknya dapat mengontrol menggunakan gadget saat berada di sekolah. Saat pembelajaran berlangsung siswa sebaiknya tidak menggunakan atau tidak mengaktifkan 
gadget supaya dapat berkonsentrasi dengan baik dan mendapatkan hasil belajar yang maksimal dan guru sebaiknya ikut mengawasi penggunaan gadget selama berada di kelas atau saat pembelajaran berlangsung serta mengontrol kelas yang memiliki jam kosong agar suasana belajar lebih kondusif. Dan sebaiknya siswi memanfaatkan gadget sebagai alat bantu dalam meningkatkan prestasi belajar.

\section{DAFTAR PUSTAKA}

[1] Badan Pusat Statistik Provinsi Riau. (2016) Profil Badan Pusat Statistik Riau : Pekanbaru : BPS Riau.

[2] Badan Pusat Statistik Kabupaten Indragiri Hilir. (2018) Profil Badan Pusat Statistik Inhil : Tembilahan : BPS Inhil

[3] Badan Pusat Statistik Indonesia (2018) Profil Badan Pusat Statiatik Dunia : BPS Dunia

[4] Febrian, Prisca L,. Denny $P_{r}$. (2014) Hubungan Antara Konsep diri dengan Prestasi Belajar Siswa Kelas XII IPA 2 Tahun Ajaran 2013/2014 di SMA Dharma Putra Tangerang : Jakarta : Jurnal Komunikasi dalam Masyarakat (27) April.pp.62-66.

[5] Hidayat, A.Alimul. (2010) Metode Penelitian Kebidanan dan Teknik Analisa Data : Jakarta : Salemba Medika.pp.2062.

[6] Hidayat, A.Alimul. (2014) Metode Penelitian Kebidanan dan Teknik Analisa Data : Jakarta : Salemba Medika.pp.30141.

[7] (http://repositori.uin-alauddin.ac.id Diakses pada tanggal 25 April 2018).

[8] Kusmiran, Eny. (2011). Kesehatan Reproduksi Remaja dan Wanita : Jakarta : Salemba Medika.

[9] Oktario, Alexander. (2017) Hubungan antara Intensitas Penggunaan Smartphone dan Motivasi Berprestasi Pada Mahasiswa : Yogyakarta: Jurnal Komunikasi dalam Masyarakat (23)April.pp.16-63.

[10] Putri, A,.R,.Noviana. (2016) Hubungan Tingkat Penggunaan Smartphone Pada Remaja Dengan Interaksi Dalam Keluarga : Jakarta : Jurnal Komunikasi dan Pengembangan Masyarakat (27) April.pp.11-20.

[11] Rezani, (2012) Peningkatan Prestasi Belajar Siswa pada Pembelajaran menggunakan mesin untuk Operasi Dasar dengan Bantuan Modul di SMK Islam Yogyakarta : Yogyakarta : Jurnal Kesehatan Masyarakat
Agustus.pp.1-56.

[12] Rohmah Chusna (2017) Pengaruh Penggunaan gadget dan Lingkungan Belajar terhadap minat belajar siswa kelas XI Kompetensi Keahlian Administrasi Perkantoran SMK Muhammadiyah 2 Yogyakarta dimana populasi penelitian adalah Student Grade XI Office Administration Competence SMK Muhammadiyah 2 Yogyakarta : Yogyakarta : Jurnal Komunikasi dalam Masyarakat (26).pp.1-20.

[13] Sastroasmoro \& Sofyan. (2010) Dasardasar Metodologi Penelitin Klinis : Jakarta: Sagung Seto.

[14] Sumantri $\quad H$,.Arif. (2017)Metodologi Penelitian Kesehatan : Jakarta : Adhitya Andrebina Agung.pp.209-241. 